\title{
MACRO AND MICROMORPHOLOGIC INDICATORS OF PHYSICAL CLAYEY RED LATOSOL CULTIVATED WITH SUGARCANE
}

\author{
Adriana Aparecida Silva * \\ Selma Simões de Castro **
}

Indicadores Macro e Micromorfológicos da Qualidade Física

de um Latossolo Vermelho Cultivado com Cana-de-Açúcar

\begin{abstract}
Resumo
O sudoeste do estado de Goiás se destaca no processo de expansão recente do cultivo da cana-de-açúcar, em especial a microrregião de Quirinópolis, onde inicialmente foram substituídas áreas de cultura anual, sobretudo soja, e em seguida áreas de pastagem, sobre Latossolo Vermelho distroférrico argiloso (LVdf), que apresenta alto potencial de compactação. O objetivo desse trabalho foi avaliar o processo de compactação de tais solos cultivados com cana-de-açúcar, considerando que os perfis selecionados foram descompactados, corrigidos e fertilizados antes do plantio da cana. Tais perfis apresentam diversas formas de usos anteriores à cana (soja/cana, pasto/cana e sucessão pasto/soja/cana), além do manejo com e sem fertirrigação com vinhaça, e tiveram como referência área remanescentes de vegetação natural. Foram avaliados indicadores macro e micromorfológicos, ensaios de resistência mecânica à penetração e análises físico-hídricas em laboratório. Os resultados indicaram compactação superficial e subsuperficial dos perfis estudados, independente dos usos anteriores, sendo os principais indicadores a presença de estrutura tendendo a laminar pouco porosa nos níveis compactados, além de aumento da densidade do solo e da resistência mecânica à penetração.
\end{abstract}

Palavras-chave: Saccharum spp; Estrutura; Compactação; Micromorfologia.

\begin{abstract}
The southwest of Goiás stands out in the process of the recent expansion of sugarcane plantation, especially in micro-region of Quirinópolis, where previously areas of annual crops were replaced, especially soybeans, and then pasture areas on clayey dystroferric Red Latosol (LVdf) which has a high potential for compaction. The aim of this work was to evaluate the process of compaction such soils cultivated with sugarcane, considering the selected profiles were decompressed, corrected and fertilized before planting sugarcane. Such profiles have along with the current use of sugarcane varying in relation to previous use (soybean/sugarcane, pasture/sugarcane and pasture succession/soybean/sugarcane), and the management with and without fertigation with vinasse, and an area of remaining natural vegetation as control. Macro and micromorphological indicators, followed by tests evaluated in laboratory as penetration resistance and physic-hydric analysis. The results indicated surface and subsurface compaction of the soil profile studied, regardless of previous uses, being the main indicators the presence of structure tending to laminar few porous in compaction levels, and increased of soil density and of penetration resistance.
\end{abstract}

Key words: Saccharum spp; Structure; Compaction; Micromorphology.

\begin{abstract}
Resumen
El sudoeste del estado de Goiás se destacó en la reciente expansión del cultivo de caña-de-azúcar, en particular la microrregión del Quirinópolis donde fueron sustituidos áreas de cultivos anuales, sobre todo soja, y luego áreas de pastoreo, en los Oxisol distrófico arcilloso (LVdf), que tiene un alto potencial para la compactación. El objetivo de este estudio fue conocer el proceso de compresión de tales suelos cultivados con caña-de-azúcar, mientras que los perfiles seleccionados fueran descomprimidos, corregidos y fertilizados antes de lo plantío de caña. Estos perfiles presentan diversas formas de uso antes de la caña de (soja/caña, pasto/caña y sucesión pasto/soja/caña), y el manejo con y sin fertirrigacion con vinaza, y se basaron en área de vegetación natural. Se evaluaron indicadores macro y micromorfológicos, pruebas de la resistencia mecánica a penetración y análisis físico-hidro del laboratorio. Los resultados indicaron compactación superficial y subsuperficial de los perfiles estudiados, independientemente de los usos anteriores, los principales indicadores la presencia de estructura tendiendo a laminares y ligeramente porosa en los niveles comprimidos y el aumento de la densidad aparente del suelo y de la resistencia a la penetración.
\end{abstract}

Palabras clave: Saccharum spp; Estructura; Compresión; Micromorfología.

(*) Lecturer on the Geography Postgraduate Programme at the Universidade Estadual de Goiás - Av. Juscelino Kubitschek, 146, CEP: 75.110-390. Anápolis (GO), Brasil. Tel.: (+55 62) 3328 - 1128 - ueg.adriana@gmail.com

(**) Lecturer on the Geography Postgraduate Programme at the Universidade Federal de Goiás - Av. Esperança, s/n, CEP: 74.690-900. Tel.: (+55 62) 3521-1184 - selma@iesa.ufg.br 


\section{INTRODUCTION}

The expansion process of sugarcane has intensified in the state of Goiás since the late 1990s, achieving in 2012 a planted area of about 730 thousand ha, highly concentrated in the portion center/south of the State, particularly on the southwest planning region (SEPLAN, 2006). In this Micro-Region of Quirinópolis (MRQ), that stands out by presenting three of the ten municipalities with large areas of sugarcane production in the state: Quirinópolis with 48,233 ha, Gouvelândia with 23,245 ha and Caçu with 20,261 ha, respectively the first, sixth and tenth in the ranking (CANASAT, 2012).

The sugarcane planting in MRQ began in 2004, induced by the implementation of two large Plants in the region (São Francisco Plant and Boa Vista PLant). The first crop was harvested in $2006 / 2007$ on a planted area of 5,688 ha, this area has expanded rapidly reaching 125,896 thousand ha in 2011/2012 (CANASAT, 2012). The initial planting occurred in the best soil on the region, the clayey dystroferric Red Latosol (LVdf), until then cultivated with grains especially soybean and maize, replacing pastures areas, in some cases replacing by successional sequence of the pasture/ soybean/sugarcane, aiming a recovery of degraded soil by pasture. However, the area with LVdf is relatively small and mainly concentrated on basaltic land in northeast, where grains were cultivated later was quickly occupied by sugarcane. This cultivation began to expand on other soils, among them the dystrophic Red Latosol occupy larger areas on sandstones towards the center of the MRQ resulting in textures with less clay, therefore destined to pastures (SILVA; CASTRO, 2011).

The LVdf is characterized by presenting homogeneous profile, texture clayey to very clayey and being associated with a plan relief until smooth wavy, is therefore considered of elevated agricultural potential for intensive cultivations, even if liable to correction and fertilization. Clayey soils are highly susceptible to compaction (DIAS JÚNIOR, 2000; REICHERT, et al. 2007.; TRINDADE et al., 2008), which is potentially maximized when associated with a technified management by heavy machinery use, as on case of sugarcane cultivation in the MRQ. Thus, there is a need to adopt criteria to assess the current conditions of soils quality, especially considering the compaction potential and the fact that the expansion of sugarcane cultivation is recent on this area.

The Soil Quality (SQ) is understood as the soil ability to exercise functions within the limits of land use capacity, as environmental quality parameter, excluding the soil just as a production factor (DORAM; PARKIN, 1994). The compaction prejudice the soil quality for reduce your macroporosity, increases your density and resistance, because difficult roots penetration and your proper breathing and mineral nutrition (REICHERT et al., 2007).

This study propose was evaluate the physical quality of LVdf with emphasis on the structure, since from the point of view of agricultural use is considered the most important of soil properties, by condition the porosity and water supply and air for plants (SCHNEIDER et al., 2007; PEDROTTI; MÉLLO JÚNIOR, 2009). According to Soares et al. (2005a) the mechanical practices that most affect soil structure, result of traffic of heavy machinery and the intensive use of agricultural implements modifying the size of the aggregates and reduce porosity. What causes an increase in the proportion of small pores (micropores) in relation to large (macropores), as also modify your forms and connectivity (morphoporosity). Several authors highlight these transformations affect particularly the monoculture of sugarcane, due to heavy machinery, promoting deformation on structure (changing from aggregate to laminar), increased soil density and mechanical resistance to roots penetration (OLIVEIRA et al., 2003; SEVERIANO et al., 2008; OTTO et al., 2011; PACHECO; CANTALICE, 2011).

The aim of this paper was to present the macro and micromorphological indicators of physical quality of LVdf in MRQ, cultivated with sugarcane, related to the management (not fertirrigated or 
fertirrigated with vinasse) and previous uses, aiming to characterize and discuss comparatively the compaction process. For this, the study was developed in six areas specially selected, representing previous uses (succession soybean/sugarcane, pasture/sugarcane and pasture/soybean/sugarcane) and current management with or without fertigation with vinasse, having for control purposes an area with natural vegetation.

\section{MATERIALS AND METHODS}

\section{Study Area}

The MRQ has a total area of 16,068 square kilometers equivalent to 1,606,803 ha, located on planning area referred as Goiás Southwest (SEPLAN, 2006), composed of nine municipalities, among them Quirinópolis and Gouvelândia, where concentrate large continuous areas of sugarcane cultivation. In 2004, before the arrival this monoculture, predominant use was extensive pasture, occupying $72.6 \%$ of the area, followed by natural vegetation with $15.4 \%$ and annual crops with $9.3 \%$, the other uses sum less than 3\% (SILVA; CASTRO, 2011). According those same authors, in 2010 the sugarcane already occupied $7.23 \%$ of the area, initially replacing areas annual crop (grains) and subsequently pasture area which reduced to 57.63. The annual crops, especially soybean, although it has been the main area of production, which showed an increase in area planted passing to $16.68 \%$ because was displaced on pasture area, as indicated by Castro et al. (2010), or was planted just for one crop cycle for the purpose to recover degraded pastures destined later planting sugarcane, in others words, succession implementation pasture/soybean/sugarcane is common practice in the soil preparation in this micro-region (SILVA; CASTRO, 2011).

The LVdf are considered the greatest soils of agricultural potential in the MRQ and all the South Goiás, in which were annual crops, besides that, its initial preparation was facilitated because, was ground of short and intensive cycle crops generally rotated (soybean/maize), therefore the lands were previously well prepared for sugarcane cultivation. Such soils are located mainly northeast in MRQ, composed of basalts from Serra Geral Formation/São Bento Group, that guarantee better texture and fertility condition (SOUZA JÚNIOR, 1983). In relation to relief, this area is part of the Regional Surface Planing IVB, with altitude quotas between 400 and 550m, associated with low slopes and poor dissection, besides favored by many drainage channels and the presence of lacustrine systems (LATRUBESSE; CARVALHO, 2006). Therefore, in addition to soils, the relief is also highly favorable to the sugarcane cultivation and also has abundance surface water supply.

Six homogeneous sample areas was selected in same environmental conditions, among them, five areas with current use of sugarcane, which were submitted at the same initial preparation of decompaction and chemical fertility correction, representative of the cultures replacement process 
(soybean/sugarcane, pasture/sugarcane and pasture/soybean/sugarcane) (Box 1), plus a control area with natural vegetation preserved.

Box 1 - Soil preparation applied in region of Quirinópolis, Goiás.

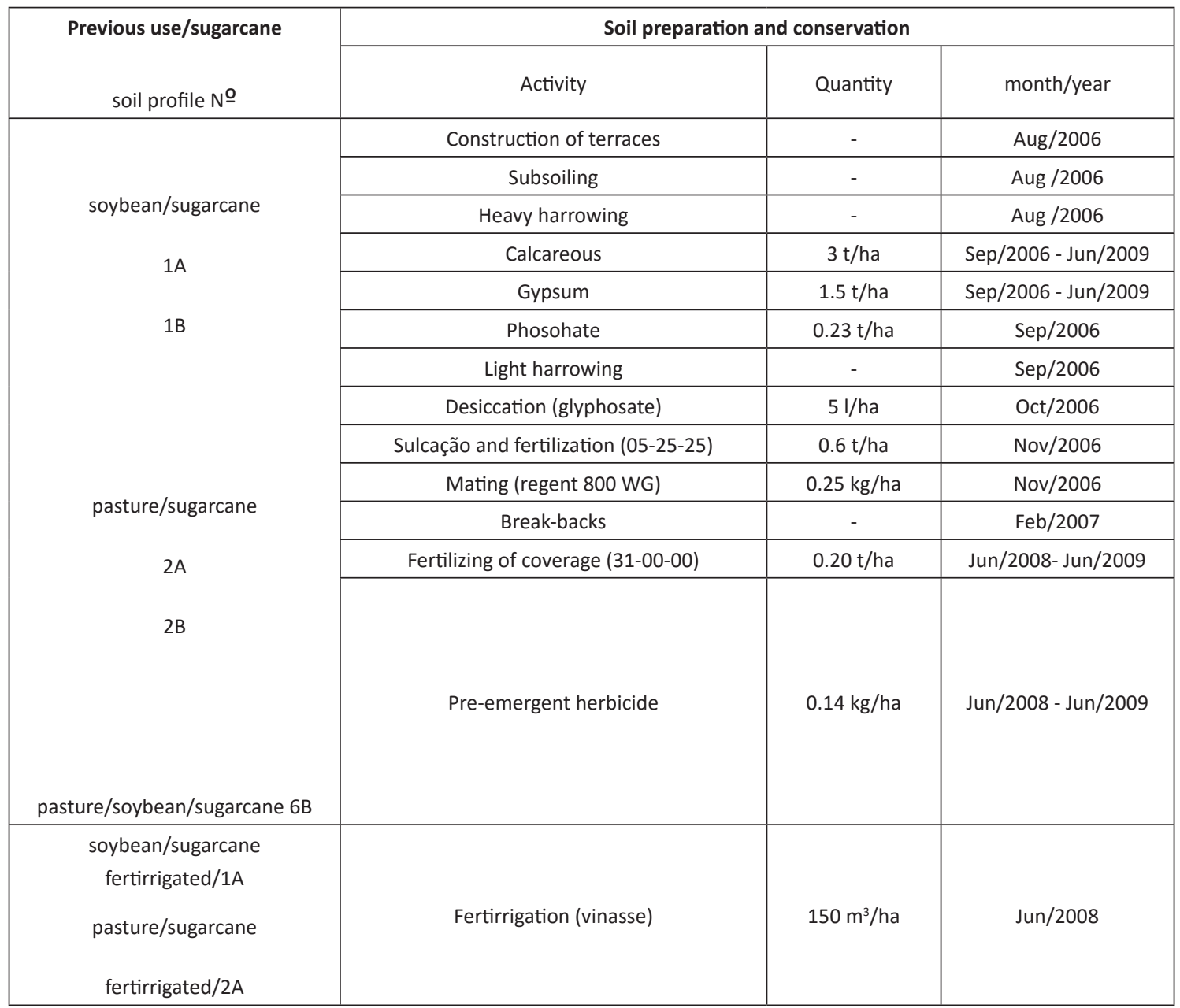

Number followed by letter A management fertirrigated; Number followed by letter B management not fertirrigated.

\section{Methodology}

Morphological descriptions and samples were taken in conventional trench profile method, based on Santos et al. (2005), emphasizing the thickness, texture, structure, consistency, porosity, presence of compaction structures, its characteristics and effects. Samples were collected from deformed and undeformed samples for tests of fertility and physical analysis. Also were collected for micromorphological study, rectangular boxes of white paperboard size $12 \times 7 \times 6 \mathrm{~cm}$ to collect monoliths of soil horizons, in addition to volumetric rings by density values.

On same level at a distance of $2 \mathrm{~m}$, adjacent the trenches, proceeded the test of mechanical resistance of soil penetration (PR), made by the vertical impact penetrometer $(60 \mathrm{~cm}), \mathrm{IAA} / \mathrm{Pla}-$ nalçucar model (STOLF 1983), which simulating the penetration of roots in soil. The penetration transformation of the equipment stem on soil (cm/impact) in PR values were obtained by following equation, in which for the conversion of $\mathrm{kgf} / \mathrm{cm}-2$ to MPa multiply the result obtained in the equation by the constant 0.0981 (STOLF, 1991).

$\mathrm{R}(\mathrm{kgf} / \mathrm{cm} 2)=5.6+6.89 \mathrm{~N}$

Where: $\mathrm{R}=$ soil resistance or cone index and $\mathrm{N}=$ penetration unit by one impact.

In laboratory the samples were sent for analysis, being that deformed samples aimed at textural analysis (in water and $\mathrm{NaOH}+$ Sodium Hexametaphosphate by method densimeter), clay 
dispersed in water, flocculation degree, gravimetric humidity and organic matter content (Sodium Dichromate) (EMBRAPA, 1997). Already the undeformed samples, collected in volumetric rings, served the determination of bulk density (volumetric ring method), particle density (volumetric flask method) and calculation of total porosity (EMBRAPA, 1997). Other undeformed samples, the monoliths, were sent for laboratory, where were dried at $40^{\circ} \mathrm{C}$, after under vacuum then impregnated with polyester resin for later cut, glued and polished to achieve a thickness of $25 \mu \mathrm{m}$ (CASTRO et al., 2003). The micromorphological parameters observed were: fabric, matrix components, microstructure, porosity and dominant pedological features. Descriptions were made according to Stoops's (2003) instructions, with support of the binocular petrographic microscope (Olympus model BX40), in which was coupled digital camera for taking photomicrographs.

\section{RESULTS AND DISCUSSION}

\section{Macromorphological Attributes}

The results in Box 2 show that the 1A profile (succession soybean/sugarcane fertirrigated), 1B profile (soybean/sugarcane not fertirrigated), 2A profile (pasture/sugarcane fertirrigated) and $6 \mathrm{~B}$ profile (pasture/soybean/sugarcane not fertirrigated) developed structure in small to medium subangular blocks on surface horizons (A, AB and BA), as contrasted with the small granular structure to very small, typical of the Red Latosols, from subsurface horizons Bw1 and Bw2. In the $2 \mathrm{~B}$ profile (pasture/sugarcane not fertirrigated) the structure already shows large laminar in the horizons $\mathrm{A}$ and $\mathrm{AB}$, in subangular blocks in Bw1 and only granular in the Bw2. The 7C profile (natural vegetation) presents a granular structure for lumpy on the A horizon and granular small to very small in the $\mathrm{AB}, \mathrm{BA}$ and $\mathrm{Bw}$. Such structures allow determine that, in general, there is a predominance of structures in small to medium blocks on the surface horizons from profiles with sugarcane, whose consistency is in general hard when dry, but friable to very friable when moist and not indicative of compaction, except in 2B profile that continues more consistent (very firm), indicating compaction. However, the blocks indicate change in original granular structure, which may indicate low compression that is not enough to promote limitations on growth of roots.

The consistency when presented firm becomes friable to very friable in subsurface horizons, except for the $\mathrm{AB}$ horizon of the $2 \mathrm{~B}$ profile, where consistency is still very firm, indicating probable effect of the type "pé-de-grade". The plasticity and stickiness, concerning the wet consistency, indicate that it is very plastic and sticky when managed soil at field capacity, allowing the evaluation that it is high potential for compaction, as is the case of $2 \mathrm{~B}$ profile (pasture/sugarcane not fertirrigated), 1A profile (soybean/sugarcane fertirrigated) and 1B profile (soybean/sugarcane not fertirrigated).

In general the morphological features presented suggest that already occurs structural degradation, although incipient, compatible with soil compaction, by the presence of developed blocks from the granular structure, typical of these soils, evolving to laminar, besides the dry hard consistency to very hard and very firm when moist in $2 \mathrm{~B}$ profile, that already indicate compaction. Studying similar soils, Kertzman (1996) defined the consistencies hard at very hard, when in the dry state, as indicators of medium to high degree of compaction. Applying this interpretation of the profiles now studied, the biggest structural change is observed in the $2 \mathrm{~B}$ profile on the replacement pasture/ sugarcane not fertirrigated, due to the presence of very hard laminar structure on the horizons A and $\mathrm{AB}$, and firm to very firm in the moist state, however in the other profiles the presence of hard consistency already indicate compaction. Such characteristics were attributed to intensive heavy machinery management of sugarcane in clayey soils and very plastic, besides the case 2B profile, where the soil preparation occurs in humid period, according with report of management provided by the San Francisco Plant. 
Box 2 - Morphological attributes of dystroferric Red Latosol.

\begin{tabular}{|c|c|c|c|c|c|}
\hline \multirow{2}{*}{$\begin{array}{l}\text { horizon } \\
\mathrm{cm}\end{array}$} & \multirow[b]{2}{*}{ Structure } & \multicolumn{3}{|c|}{ Consistency } & \multirow[b]{2}{*}{ Transition } \\
\hline & & dry & moist & wet & \\
\hline \multicolumn{6}{|c|}{ 1A profile-soybean/sugarcane fertirrigated } \\
\hline A $0-13$ & Small subangular blocks & $\mathrm{H}$ & $\mathrm{FL}$ & FPL, FST & G,W \\
\hline$A B 13-50$ & Medium to small subangular blocks & $\mathrm{SH}$ & $\mathrm{FI}$ & PL, VST & $\mathrm{D}, \mathrm{W}$ \\
\hline BA $50-90$ & Small subangular blocks & $\mathrm{H}$ & FR & $\mathrm{PL}, \mathrm{VST}$ & C, W \\
\hline Bw1 $90-110$ & Small granular & $\mathrm{SH}$ & FR & PL, VST & $\mathrm{D}, \mathrm{W}$ \\
\hline $\begin{array}{c}\text { Bw2 110- } \\
150+\end{array}$ & Small granular & $\mathrm{S}$ & VFR & $\mathrm{PL}, \mathrm{STI}$ & \\
\hline \multicolumn{6}{|c|}{$\begin{array}{l}\text { 1B profile-soybean/sugarcane not fertirrigated } \\
\text { Medium subangular blocks }\end{array}$} \\
\hline A $0-23$ & Medium subangular blocks & $\mathrm{H}$ & $\mathrm{Fl}$ & FST & $N$ \\
\hline $\mathrm{AB} 23-65$ & Medium to small subangular blocks & $\mathrm{MD}$ & $\mathrm{FI}$ & STI & \\
\hline BA $65-88$ & Small subangular blocks & $\mathrm{MD}$ & $\mathrm{Fl}$ & VST & \\
\hline Bw188-116 & Small subangular blocks & $\mathrm{SH}$ & FR & $\mathrm{PL}, \mathrm{VST}$ & $\mathrm{D}, \mathrm{W}$ \\
\hline $\begin{array}{c}\text { Bw2 116- } \\
150+\end{array}$ & Small granular & S & VFR & PL, VST & \\
\hline \multicolumn{6}{|c|}{ 2A profile- pasture/sugarcane fertirrigated } \\
\hline $\mathrm{A} 0-33$ & Small subangular blocks & $\mathrm{S}$ & VFR & SST & \\
\hline $\mathrm{AB} 33-47$ & Medium to small subangular blocks & $\mathrm{SH}$ & $F R$ & STI & \\
\hline BA 47-77 & Small subangular blocks & SH & FR & & \\
\hline Bw1 $77-115$ & Small granular & $\mathrm{S}$ & FR & $\mathrm{LPL}, \mathrm{SST}$ & $\mathrm{D}, \mathrm{F}$ \\
\hline $\begin{array}{c}\text { Bw2 } 115- \\
150+\end{array}$ & Small granular & $\mathrm{S}$ & VFR & SPA, SST & \\
\hline \multicolumn{6}{|c|}{ 2B profile-pasture/sugarcane not fertirrigated } \\
\hline $\mathrm{A} 0-15(20)$ & Large laminar & $\mathrm{MD}$ & VFI & LPL, SST & $\mathrm{D}, \mathrm{W}$ \\
\hline $\begin{array}{c}A B 15-53 \\
(65)\end{array}$ & Large laminar & MD & VFI & LPL, FST & $D, F$ \\
\hline Bw1 $53-102$ & Medium subangular blocks & $\mathrm{SH}$ & VFR & LPL, VST & $\mathrm{G}, \mathrm{W}$ \\
\hline $\begin{array}{c}\text { Bw2 } 102- \\
150+\end{array}$ & Small granular & SH & VFR & VPL, VST & \\
\hline \multicolumn{6}{|c|}{ 6B profile-succession pasture/soybean/sugarcane not fertirrigated } \\
\hline $\mathrm{A} 0-28$ & Small subangular blocks & $\mathrm{SH}$ & FR & NPL, SST & C. W \\
\hline$A B 28-56$ & Small subangular blocks & $\mathrm{SH}$ & $\mathrm{FR}$ & LPL, SST & $A, F$ \\
\hline Bw1 $56-90$ & Small subangular blocks & $\mathrm{SH}$ & VFR & LPL, SST & $A, F$ \\
\hline $\begin{array}{c}\text { Bw2 } 90- \\
150+ \\
\end{array}$ & Small granular & S & VFR & LPL, SST & \\
\hline \multicolumn{6}{|c|}{ 7C profile- natural vegetation } \\
\hline $\mathrm{A} 0-20$ & Small to lumpy granular & $\mathrm{H}$ & VFR & VPL, STI & G,F \\
\hline$A B 20-53$ & Small granular & $\mathrm{SH}$ & VFR & $P L, S T I$ & $\mathrm{G}, \mathrm{F}$ \\
\hline BA $53-90$ & Large angular blocks that break into small granules & $\mathrm{SH}$ & VFR & LPL, STI & C, W \\
\hline Bw1 90- 130 & Large angular blocks that break into small granules & $\mathrm{S}$ & VFR & FPL, FST & C, F \\
\hline $\begin{array}{c}\text { Bw2 } 130- \\
150+\end{array}$ & Small angular blocks & $S$ & VFR & PL, STI & \\
\hline
\end{tabular}

Dry consistency: $\mathrm{S}=$ soft, $\mathrm{SH}=$ slightly hard, $\mathrm{H}=$ hard, $\mathrm{VH}=$ very hard; Moist consistency: $\mathrm{VFR}=$ very friable, $\mathrm{FR}=$ friable, $\mathrm{FI}=$ firm; $\mathrm{VFI}=$ very firm; Wet consistency: $\mathrm{NPL}=$ not plastic, $\mathrm{FPL}=$ few plastic, $\mathrm{SPA}=$ slightly plastic, $\mathrm{PL}=$ plastic, $\mathrm{VPL}=$ very plastic; $\mathrm{FST}=$ few sticky; $\mathrm{SST}=$ slightly sticky, $\mathrm{STI}=$ sticky, $\mathrm{VST}=$ very sticky;

Transition: $\mathrm{A}=$ abrupt, $\mathrm{C}=$ clear, $\mathrm{G}=$ gradual, $\mathrm{D}=$ diffuse; $\mathrm{F}=$ flat; $\mathrm{W}=$ wavy, $\mathrm{I}=$ irregular, $\mathrm{D}=$ discontinuous.

Considering a comparison between the six profiles, the $7 \mathrm{C}$ profile is the only one who was uncompacted, as expected. Among managed, the least degraded was the $2 \mathrm{~A}$ profile (pasture/sugarcane fertirrigated) that presents a structure in small blocks with soft consistency on the horizons A, Bw1 and $\mathrm{Bw} 2$, and slightly hard in $\mathrm{AB}$ and $\mathrm{BA}$, but very friable at friable in the wet state. Can say that the profiles $1 \mathrm{~A}, 1 \mathrm{~B}, 2 \mathrm{~A}$ and $6 \mathrm{~B}$ show low compaction and $2 \mathrm{~B}$ profile presents strong compaction in the surface horizons. In none of them was affected Bw horizon, at maximum until the BA horizon, because is surface compaction.

Even having gone through the same mechanical preparation process of the decompaction (subsoiling, heavy harrowing and light harrowing, according box 1), which would have greatly reduced or even eliminated the acquired compaction of crops and previous managements, can be observed that the nowadays behavior of soils under sugarcane is not uniform between profiles. Considering that the preparation operations with heavy machinery use tend to deform the soil structure (CAMARGO; ALLEONI, 1997; DIAS JUNIOR, 2000), since 2006 in the study area were already realized three mechanized crops (June/2008, May/2009 and May/2010), with heavy machinery use. Casagrande (2002) warning that a loader cane can cause compaction in until $10 \mathrm{~cm}$ of depth, already a transport system via truck (popularly called biminhão), where body shell can take up to 30 tons each when full, can reach up to $30 \mathrm{~cm}$ of compaction. 


\section{Physic-hydric Attributes and Organic Matter Content}

The Table 1 shows analytical results relacional the texture, water dispersible clay (WDC), soil density (SD), particle density (PD), total porosity (TP) and organic matter content (OMC) of studied soils. Corroborating the field observations, the texture is clayey for all profiles studied with relatively low water dispersible clay (WDC). This can be explained by the high amounts of iron oxides, common feature of soils derived from basaltic rocks as the LVdf. The highest content of WDC occurs only in the A horizon of 1A profile (soybean/sugarcane fertirrigated) and 2A profile (pasture/sugarcane fertirrigated), but curiously also in the $7 \mathrm{C}$ profile (vegetation) which may indicate that the soil itself would already have this feature.

At all events, in the other horizons of this $7 \mathrm{C}$ profile and in others, the dispersion is too low $(<4 \%)$, it is zero in all the horizons of the $6 \mathrm{~B}$ profile (succession pasture/soybean/sugarcane not fertirrigated). Some authors consider that the vinasse improves soil aggregation which would allow greater water infiltration and decreased WDC, varying in relation to its constitution, amounts of $\mathrm{OMC}$ and of cations $\mathrm{K}+, \mathrm{Ca} 2+\mathrm{e} \mathrm{Mg} 2+(\mathrm{RIBEIRO}$ et al., 1983). However, not was observed notable difference between fertirrigated profiles and not fertirrigated. It must be noted that is the total OMC, which corrected for organic $C$ will indicate low levels, except for horizons $A$ and $A B$, as expected, probably due to the cultivation on sugarcane straw.

Inversely proportional to WDC, the flocculation degree (FD) shows higher values in subsurface horizons in relation to the surface horizons, as expected, because they were little affected by the management. The $6 \mathrm{~B}$ profile presented all horizons with clay $100 \%$ flocculated, as is proper this type of soil.

Datas relating to physic-hydric attributes and of the $\mathrm{OMC}$, comparing the profiles of the sugarcane with the control area indicate that occured changes in the physical quality of the soil. The indices presented by Kertzman (1996), were considered as parameters for soils with same characteristics, which the SD values between 1,2 and 1,39 $\mathrm{g} \mathrm{cm}-3$ are indicative of average compacting, and values higher than 1,40 for high compacting, the latter value considered critical by Reynolds et al. (2002). In the analyzed profiles, compatible values with high compaction were found in horizons $\mathrm{A}$ and $\mathrm{AB}$ of the $2 \mathrm{~B}$ profile (pasture/sugarcane not fertirrigated) and medium compaction for the profile $1 \mathrm{~B}$ (soybean/sugarcane not fertirrigated). In relation to $\mathrm{TP}$, even according to these same authors, values less than $54 \%$ are indicative of high compaction, as found in horizons $\mathrm{A}$ and $\mathrm{AB}$ of the profiles $2 \mathrm{~B}, 1 \mathrm{~B}$ and $6 \mathrm{~B}$ all related to management not fertirrigated (figure 1).

Considering the cultivation of sugarcane on straw, which provides $\mathrm{OMC}$ to soils, all horizons $\mathrm{A}$ of the profiles $1 \mathrm{~A}, 1 \mathrm{~B}, 2 \mathrm{~A}$ and $2 \mathrm{~B}$ showed high values of $\mathrm{OMC}$, but even so lower to values profile $7 \mathrm{C}$ as reference. This did not occur in $6 \mathrm{~B}$ profile that is much lower, with traditional management, without wastes, which also causes the low TP values found. It was observed that the irrigation with vinasse have not significantly increased the OMC content of the profiles $1 \mathrm{~A}$ and $2 \mathrm{~A}$, or because of vinasse have been applied only once $(150 \mathrm{~m} 3 / \mathrm{ha})$ and below the allowed volume $700 \mathrm{~m} 3 /$ ha by years. However, there is relationship between fertirrigation and lower SD values and higher to TP on fertirrigated profiles compared to other, what it has been explained by fertigation due to vinasse capacity to contribute to OMC and thus improve soil aggregation and size of aggregates, giving it greater stability structural and porosity (macro and micro). These results confirm what was observed in similar soil by Silva et al. (2007) and Carvalho et al. (2010). 
Table 1 - Physical attributes and organic matter content of the dystroferric Red Latosol.

\begin{tabular}{|c|c|c|c|c|c|c|c|c|c|c|}
\hline \multirow{3}{*}{$\begin{array}{l}\text { Profile/Horizon } \\
\text { Depth in cm }\end{array}$} & \multirow{2}{*}{\multicolumn{3}{|c|}{$\begin{array}{l}\text { Texture } \\
\mathrm{g} \mathrm{kg}^{-1}\end{array}$}} & \multirow{3}{*}{ Textural class } & \multirow{3}{*}{$\begin{array}{c}\text { WDC } \\
\text { Soi } \\
\mathrm{g} \mathrm{cm}^{-3} \%\end{array}$} & \multirow{3}{*}{$\begin{array}{c}\text { FD } \\
\text { Part. } \\
\mathrm{g} \mathrm{cm}^{-3} \%\end{array}$} & \multicolumn{2}{|c|}{ Density } & \multirow[b]{2}{*}{ TP } & \multirow[b]{2}{*}{ OMC } \\
\hline & & & & & & & & & & \\
\hline & Sand & Silt & Clay & & & & & & $\%$ & $\mathrm{~g} \mathrm{dm}^{-3}$ \\
\hline & & & & (Profile 1A & in/suga & 81 & & & & \\
\hline AB $13-50$ & $\begin{array}{l}420 \\
400\end{array}$ & $\frac{110}{100}$ & $\frac{4 / 0}{500}$ & $\begin{array}{l}\text { Clayey } \\
\text { Clavey }\end{array}$ & 10 & $\begin{array}{l}81 \\
93\end{array}$ & $\frac{1,08}{1,07}$ & $\frac{2,18}{2,64}$ & $\frac{61}{59}$ & $\frac{17}{10}$ \\
\hline BA 50-90 & 370 & $\frac{100}{120}$ & 510 & Clayey & $\frac{4}{4}$ & 93 & 0,91 & 2,77 & 67 & $\frac{10}{6}$ \\
\hline Bw1 90-110 & 500 & 100 & $\frac{400}{210}$ & Sandy clay & $\frac{0}{2}$ & 100 & 0,94 & 2,70 & 65 & 3 \\
\hline Bw2 110-150+ & 570 & 90 & 340 & $\begin{array}{l}\text { Sandy clay } \\
\text { (Profile 1BB }\end{array}$ & $\frac{2}{\operatorname{gar}}$ & $\frac{96}{9 t \text { fertir }}$ & 1,03 & 3,14 & 67 & 2 \\
\hline A $0-23$ & 470 & 110 & 420 & Sandy clay & & & 1.28 & 2,60 & 50 & 22 \\
\hline AB 23-65 & 450 & 110 & 440 & Clayey & 2 & 97 & $\frac{1,20}{1,28}$ & 2,70 & 53 & 11 \\
\hline BA $65-88$ & 390 & 110 & 500 & Clayey & 0 & 100 & 1,13 & 2,79 & 59 & 6 \\
\hline Bw1 88-116 & 370 & 120 & 510 & Clayey & 2 & 96 & 1,11 & 2,78 & 60 & 3 \\
\hline Bw2 116-150+ & 420 & 110 & 470 & Clavey & 0 & 100 & 1,06 & 2,77 & 62 & 2 \\
\hline & & & & ofile 2 A) pas & Igarcane $\mathrm{f}$ & irrigated & & & & \\
\hline AB 33-47 & 540 & $\frac{90}{110}$ & $\frac{310}{420}$ & $\begin{array}{l}\text { Sandy clay } \\
\text { Sandy clay }\end{array}$ & $\frac{10}{0}$ & $\frac{19}{100}$ & $\frac{1.15}{1,05}$ & $\frac{2,88}{2,64}$ & $\frac{60}{60}$ & $\frac{18}{10}$ \\
\hline BA 47-77 & 460 & 110 & 430 & Sandy clay & 4 & 92 & 1,03 & 3,11 & 67 & 6 \\
\hline BW1 77-115 & 570 & 90 & 340 & Sandy clay & 0 & 100 & 1,03 & 3,11 & 67 & 2 \\
\hline Bw2 115-150+ & 690 & 70 & 240 & Sandy clay loan & 0 & 100 & 1,06 & 2,63 & 60 & 2 \\
\hline $40-15(20)$ & & 130 & 570 & Ille 2B) pas & cane $r$ & rurrigated & 150 & & 51 & 17 \\
\hline$A B-15-53(65)$ & 350 & & 530 & Clavey & $\frac{2}{2}$ & $\frac{95}{96}$ & $\frac{1.50}{129}$ & $\frac{3,00}{2,24}$ & $\frac{51}{42}$ & $\frac{17}{10}$ \\
\hline Bw153-102 & 450 & $\frac{120}{110}$ & 440 & Clayey & $\frac{2}{2}$ & 96 & $\frac{1,29}{1,10}$ & 2,65 & $\frac{42}{59}$ & $\frac{10}{7}$ \\
\hline Bw2 102-150+ & 500 & 100 & 400 & Sandy clay & 2 & 96 & 1.05 & 2.58 & 59 & 2 \\
\hline & & & & & & & & & & \\
\hline A $0-28$ & 470 & 110 & 420 & Sandy clay & 0 & 100 & 1,22 & 2,25 & 33 & 10 \\
\hline $\begin{array}{c}A B 228-56 \\
w 156-90\end{array}$ & $\frac{400}{420}$ & $\frac{120}{110}$ & $\frac{480}{470} \cdot x \cdot r \cdot$ & $\begin{array}{l}\text { Clayey } \\
\text { Clavey }\end{array}$ & $\frac{0}{0}$ & $\frac{100}{100}$ & $\frac{1,36}{1,27}$ & $\frac{2,46}{2,27}$ & $\frac{45}{44}$ & $\frac{7}{6}$ \\
\hline Bw2 90-150+ & 420 & $\frac{110}{110}$ & 470 & Clayey & 0 & 100 & $\frac{1,15}{1,15}$ & $\frac{2,21}{2,30}$ & 50 & $\frac{0}{7}$ \\
\hline & & & & CPre & natural & getation & & & & \\
\hline$\frac{A 0-20}{A B 20-53}$ & 500 & $\frac{100}{110}$ & $\frac{400}{420} \cdot \ln 10$ & $\begin{array}{l}\text { Sandy clay } \\
\text { Sandy clay }\end{array}$ & 8 & $\frac{88}{83}$ & $\frac{1,16}{1,03}$ & $\frac{2,40}{2,48}$ & $\frac{57}{58}$ & $\frac{29}{11}$ \\
\hline BA 53-90 & 370 & $\frac{110}{120}$ & 510 & Clayey & 4 & 94 & 1,00 & 2,78 & 64 & $\frac{11}{7}$ \\
\hline Bw1 90-130 & 360 & 120 & 520 & Clayey & 4 & 92 & 1,01 & 2,77 & 63 & 3 \\
\hline Bw2 130-150+ & 390 & 110 & 500 & Clavey & 0 & 100 & 0,98 & 3,13 & 69 & 2 \\
\hline
\end{tabular}

$\mathrm{WDC}=$ water dispersible clay; $\mathrm{FD}=$ flocculation degree; $\mathrm{TP}=$ total porosity; $\mathrm{OMC}=$ organic matter content.

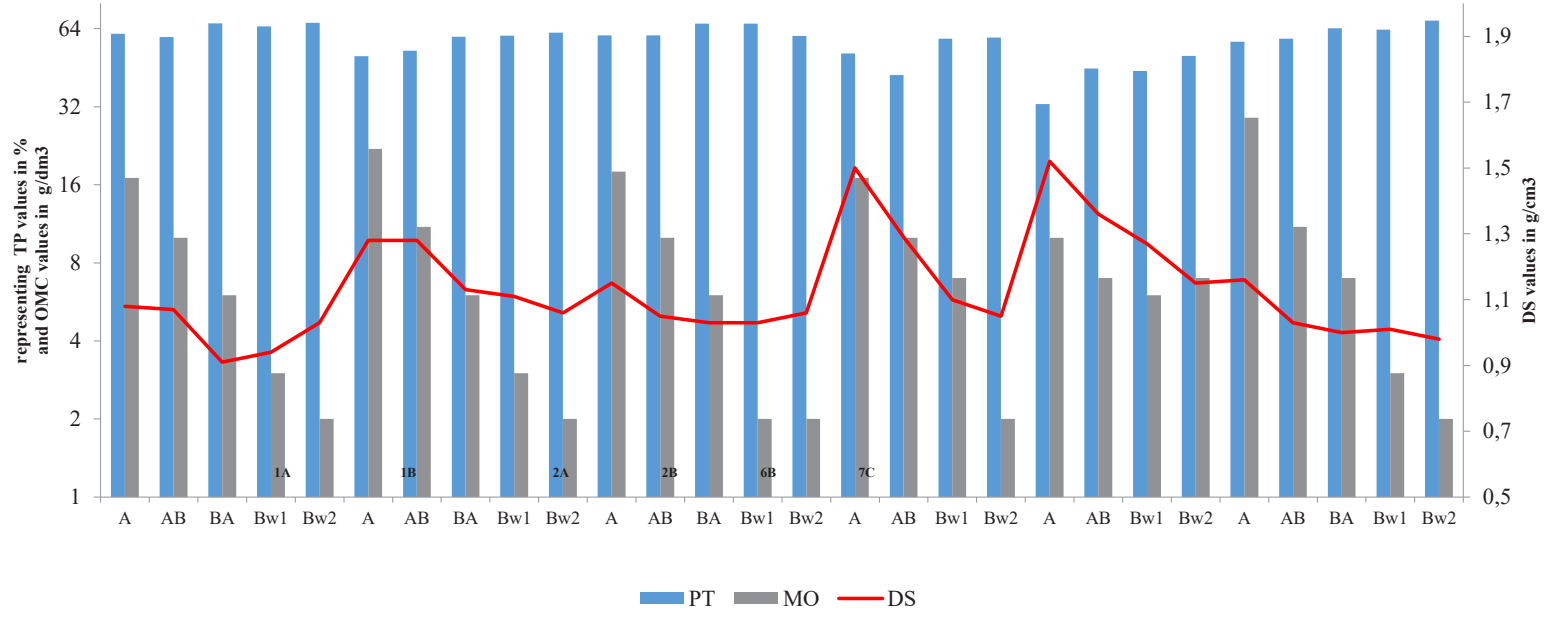

Figure 1 - Distribution of values of the SD, TP and OMC in the profiles of the dystroferric Red Latosol. $\mathrm{SD}=$ soil density; $\mathrm{OMC}=$ organic matter content; $\mathrm{TP}=$ total porosity.

Draws attention high PD values, sometimes exceeding three, indicating the presence of heavy minerals or also by the high content of iron nodules, as expected for these soils Already the fact of the $\mathrm{SD}$ values are all $<1$, including $7 \mathrm{C}$ profile, highlighting for profiles $2 \mathrm{~B}$ and $6 \mathrm{~B}$, and secondarily is indicative characteristic of compaction, this, however, still does not reveal very severe after six years of cultivation. Only two profiles $2 \mathrm{~B}$ and $6 \mathrm{~B}$, suggest more care and secondarily the $1 \mathrm{~A}$ and $2 \mathrm{~A}$, which are beginning to stand out. Therefore, the WDC and FD still have relatively satisfactory values, although longer surface reveal structural changes. The vinasse, although it has been applied only once, seems to have brought benefits however small for the structure and TP of fertirrigated profiles. 


\section{Mechanical resistence to penetration of the LVdf}

The results of the penetration resistance tests (PR) show higher values in subsurface (Figure 2 ), highlighting the 1B profile (soybean/sugarcane not fertirrigated) with $\sim 15$ to $25 \mathrm{MPa}, 2 \mathrm{~B}$ profile (pasture/sugarcane not fertirrigated) with $\sim 15$ to $20 \mathrm{MPa}$ and $1 \mathrm{~A}$ profile (soybean/sugarcane fertirrigated) relative a $15 \mathrm{MPa}$, both between 15 and $20 / 25 \mathrm{~cm}$ of depth. The $2 \mathrm{~A}$ profile (pasture/sugarcane fertirrigated) is different from the previous ones have higher resistance surface, between 0 and 20 $\mathrm{cm}(\sim 12 \mathrm{MPa})$ of depth. The profile 7C (vegetation) has the lowest PR values, as expected. The profile $6 \mathrm{~B}$ was disregarded in this comparative analysis, because the field have occurred in the wet season (early November) distinct period of other profiles with field during the dry season (early September).

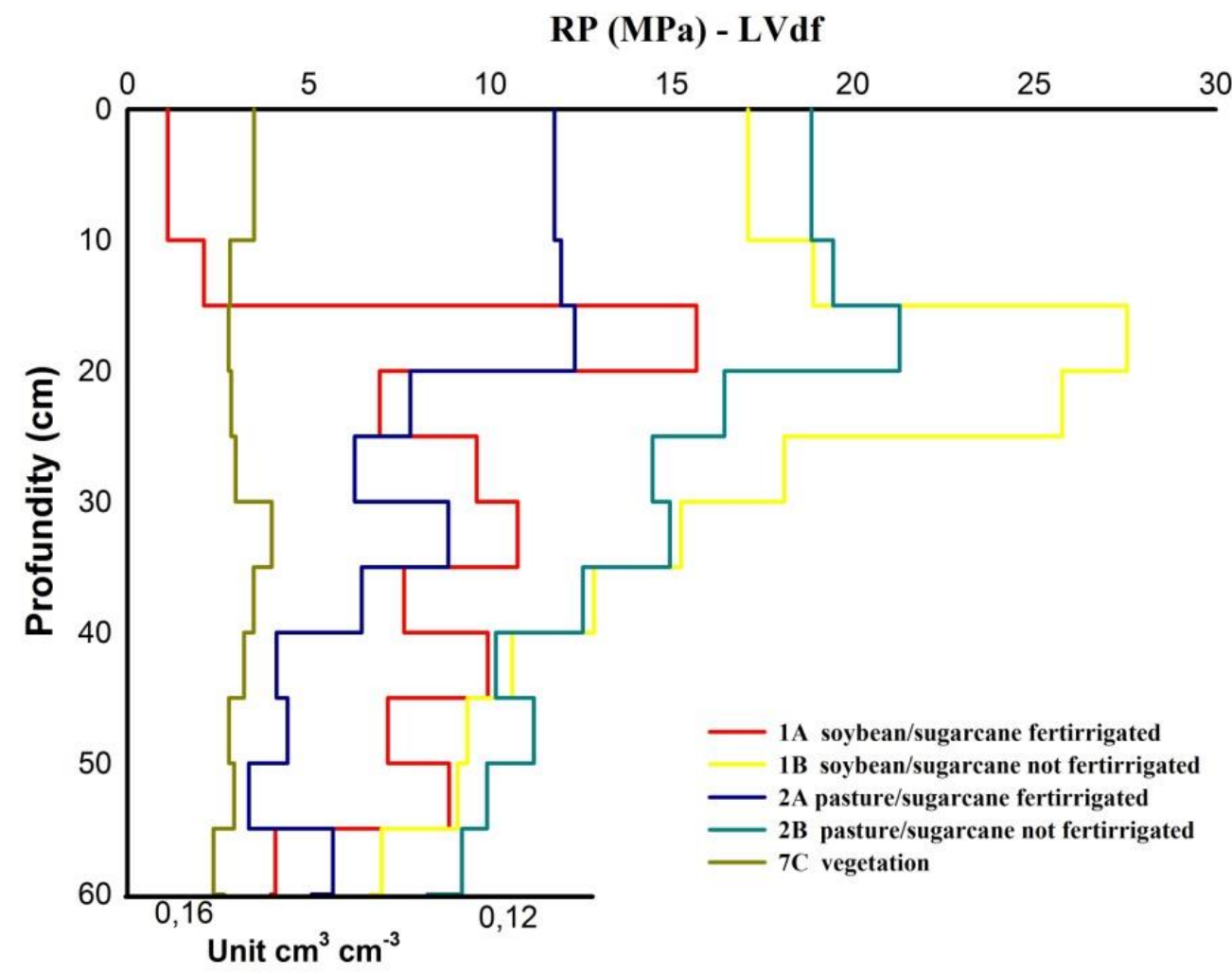

Figure 2 - PR values in profundity of dystroferric Red Latosol.

These values can be considered high and indicative of extremely high compaction, if not for the fact that the data collection was conducted in dry season, when the gravimetric humidity varies among $\sim 0,12$ to $\sim 0,16 \mathrm{~cm} 3 \mathrm{~cm}-3$, without significant changes between profiles. According Kertzman (1996) when the humidity is below field capacity, depending on the type of soil and the collection period, a 5\% increase in humidity and increases from 3 to 4 times the values of PR. Vaz et al. (2002) also found for LVdf resistance values ranging from $15 \mathrm{MPa}$ for humidity of $0,2 \mathrm{~cm} 3 \mathrm{~cm}-3$ until < $5 \mathrm{MPa}$ for humidity values $0,4 \mathrm{~cm} 3 \mathrm{~cm}-3$. These data demonstrate the dependence of moisture and PR explaining the high resistance found, because the humidity values were much lower than those detected by these authors. Proceeding to a correction in values even so stand out by the fact that PR be relatively high, reaching depths of up to $60 \mathrm{~cm}$, especially between 40 and $60 \mathrm{~cm}$, which worries due to low moisture retention of these soils, where the roots would be dependent on it.

Other factors influencing the results of $\mathrm{PR}$ are content of OMC, SD and texture, since the clay fraction increases the cohesion between the soil particles and favors the aggregation. Furthermore, the greater the clay content, less is the pore size and higher the resistance at a given density (REICHERT et al., 2010). The major PR values were observed between 0 and $25 \mathrm{~cm}$, which are most 
representative between 15 and $25 \mathrm{~cm}$, relative to $1 \mathrm{~B}$ profile (soybean/sugarcane) and $2 \mathrm{~B}$ (pasture/ sugarcane), both not fertirrigated, precisely where the SD are higher in all profiles.

In all case, in general there was a decrease in the physical quality of the soils, with slight downside to the profiles where it does not received fertigation management with vinasse, especially in the $2 \mathrm{~B}$ profile, that was prepared during the rainy season, as already explained, period of high humidity and maximum deformation. This process is compatible with high levels to moderate of soil compaction, in the surface horizons (type shallow compaction), which can be considered as a result of heavy machinery traffic, typical of the technified management of sugarcane.

These data also reinforce the idea of initial change in conditions on the physical quality of soil observed in MRQ after 6 years of cultivation and before the first reform of the sugar cane field. It is clear that the current use is associated with sugarcane as similar results by Silva and Cabeda (2006), Silva et al. (2009), Severiano (2010) and by Pacheco and Cantalice (2011), among others, for cultivated soils for longer, which indicates the intensity of the process in the MRQ. About the profiles with fertirrigated management with vinasse, these showed slightly better performance relative to the physical quality, specifically with regard to the structural indicators, SD, TP e PR, even if the treatment has not elevated substantially the OMC in the soil.

\section{Micromorphological characterization of LVdf}

Micromorphological characterization is presented in Table 2 and reveals that the profiles studied has the soil matrix composed predominantly of clay-ferruginous fine material formed by small rounded aggregates (granular structure) and, sometimes, small subrounded blocks, both separated by huddling pore inter-aggregates in subsurface Bw horizon, as expected. Already in the surface horizons perceive an increase of the small blocks at medium, also constituted from clay-ferruginous fine material, but cementing coarse grains separated by fissure pores, generally fine. However was perceived a little contribution of coarse material (sand, silt), but the presence of opaque ferruginous minerals (magnetite type) and of abundant ferruginous hematite nodules found on coarse material function. These characteristics are typical of LVdf (EMBRAPA, 2006).

In all profiles currently with sugarcane the fine material occupies the largest area in the soils layers, as in the horizons $\mathrm{A}$ and $\mathrm{AB}$, corresponding to about $80 \%$ in the profiles $1 \mathrm{~A}$ (soybean/sugarcane fertirrigated), 1B (soybean/sugarcane not fertirrigated) and 2B (pasture/sugarcane not fertirrigated). In the profiles $2 \mathrm{~A}$ (pasture/sugarcane fertirrigated) and $6 \mathrm{~B}$ (succession pasture/soybean/sugarcane not fertirrigated) represents about $60 \%$. These values decrease in depth up to the average of $50 \%$ for horizons $\mathrm{BA}, \mathrm{Bw} 1$ and $\mathrm{Bw} 2$ in the profiles $1 \mathrm{~A}$ and $1 \mathrm{~B}$, fact associated with increase of porosity. In the profiles $2 \mathrm{~A}$ and $6 \mathrm{~B}$ this reduction is less significant, even then getting between 50 to $55 \%$.

In the surface horizons of profiles $1 \mathrm{~A}, 1 \mathrm{~B}$ and $2 \mathrm{~B}$, the visible pores on slides are few about $15 \%$, finding the double $(30 \%)$ in profiles $2 \mathrm{~A}$ and $6 \mathrm{~B}$. The porosity is increased in depth, finding $30 \%$ in area from slides in the $\mathrm{Bw}$ horizons of the profile $2 \mathrm{~B}$, and $40 \%$ in the profiles $1 \mathrm{~A}, 1 \mathrm{~B}, 2 \mathrm{~A}$ and $6 \mathrm{~B}$. The reference profile $7 \mathrm{C}$ (vegetation) has higher porosity compared to profiles with sugarcane cultivation, although also with lower values surface $(\mathrm{A}, \mathrm{AB})(\sim 50 \%)$ and larger on subsurface (BA, Bw1, Bw2) $(\sim 65 \%)$. In this profile, the fine material is reduced from $<50 \%$ on the surface to approximately $20 \%$ in depth. In the set of profiles the coarse material is distributed equally and represents approximately $10 \%$ of the total area of the slide of each horizon of all profiles. The Figure 3 synthesizes what was exposed. 


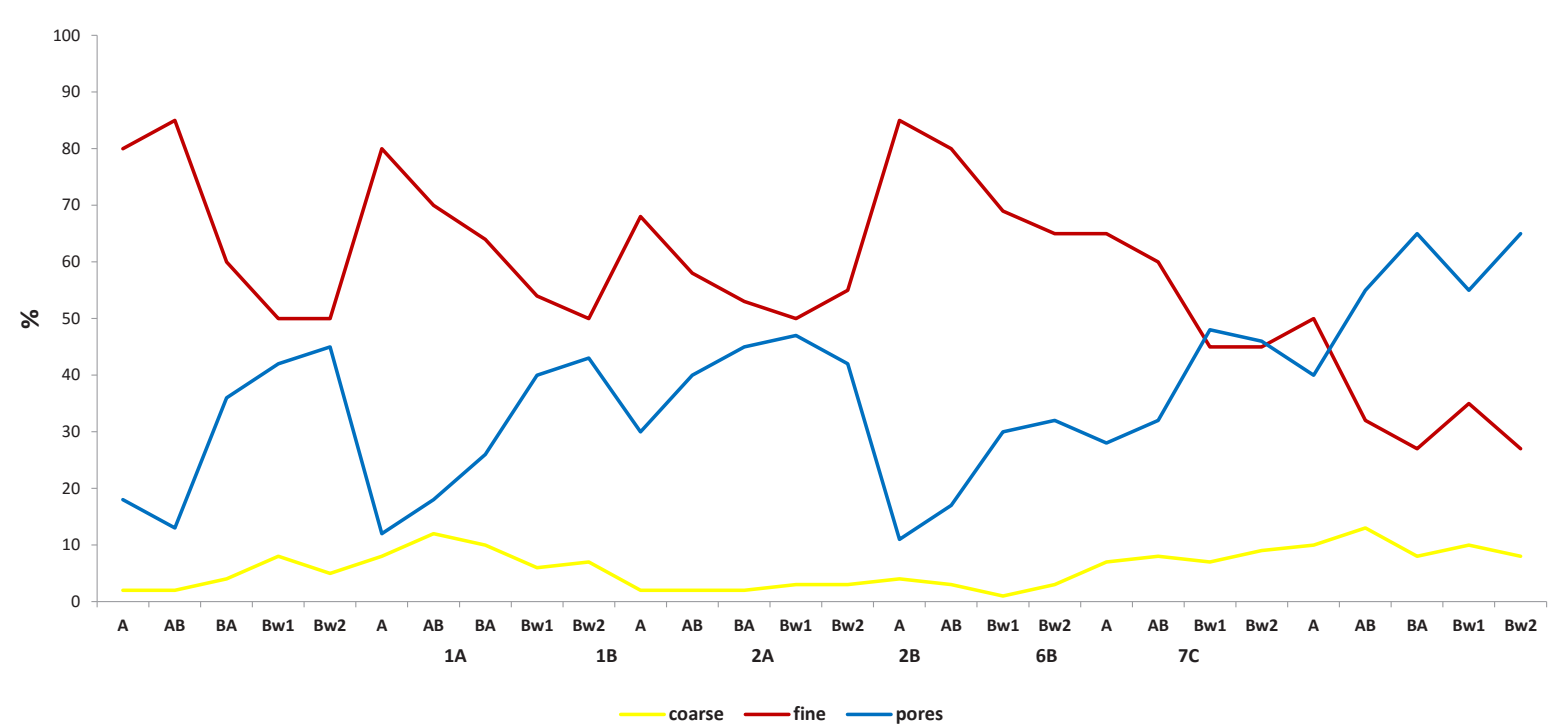

Figure 3 - Distribution of the sizes of the coarse and fine components of the matrix components and pores in thin sections of the profile of dystroferric Red Latosol (LVdf).

Table 2 - Micromorphological characterization of dystroferric Red Latosol.

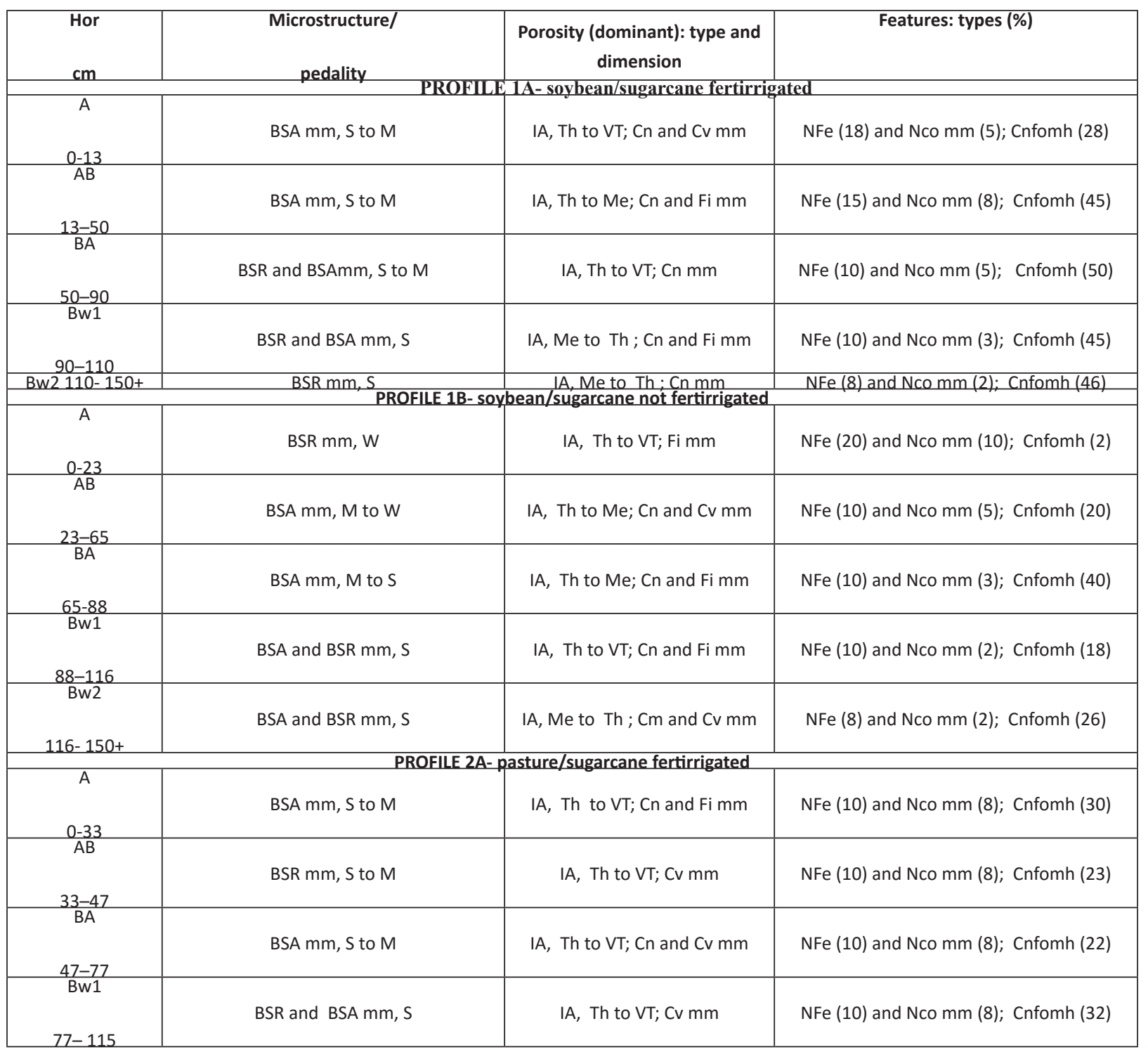


SILVA, A. A.; CASTRO, S. S.

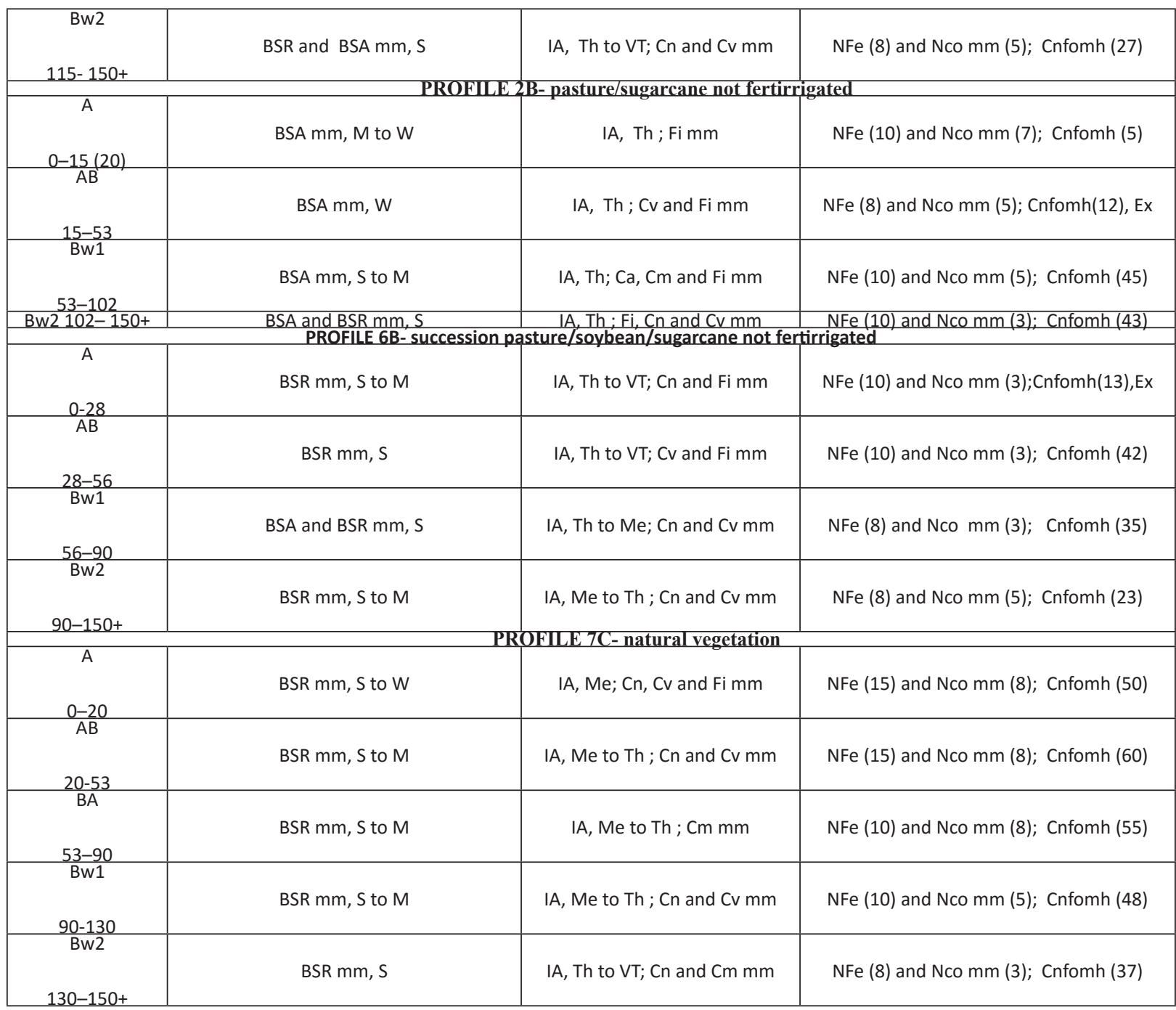

Microstructure/Pedality: $\mathrm{BSR}=$ blocks subrounded, $\mathrm{BSA}=$ blocos subangular, $\mathrm{S}=$ strong, $\mathrm{M}=$ moderate, $\mathrm{W}=$ weak; Porosity: $\mathrm{IA}=$ inter-aggregates, $\mathrm{Me}=$ medium, $\mathrm{Th}=$ thin, $\mathrm{VT}=$ very thin, $\mathrm{Cn}=$ channels, $\mathrm{Cv}=$ cavities, $\mathrm{Cm}=$ chambers, $\mathrm{Fi}=$ fissures; Features: $\mathrm{NFe}=$ nodules ferruginous, $\mathrm{Nco}=$ nodules of coal, $\mathrm{Cnfomh}=$ channels filled with its own material of the horizon, $\mathrm{Ex}=$ excrement.

Occur two types of relative distribution, an enaulic and a porphyric. The $7 \mathrm{C}$ profile (vegetation) presents a distribution relative enaulic dominant in all horizons (about $80 \%$ ), with small zones densely porphyric well distributed, corresponding to around $20 \%$ of the slides area, as expected for LVdf. Already in the other profiles 1A (soybean/sugarcane fertirrigated) and 2A (pasture/sugarcane fertirrigated) also dominates the relative distribution continues enaulic in the surface horizons A, $\mathrm{AB}$ and $\mathrm{BA}$, composing about $60 \%$ of the slides area. The densified zones corresponding to porphyric distribution representing in these profiles about $30 \%$ of the slide area in the surface horizons, decreasing to about $20 \%$ in $\mathrm{Bw}$ horizons, therefore reducing significantly in depth. Deserve to be highlighted profiles $1 \mathrm{~B}$ and $2 \mathrm{~B}$ that show in the horizons $\mathrm{A}$ and $\mathrm{AB}$ predominance of relative distribution of the porphyric type $(\sim 90 \%)$, but in the horizons BA and Bw resume the predominance of enaulic relative distribution ( $80 \%)$. The Figure 4 illustrates the exposed.

Overall, Figure 4 allows observe the predominance of enaulic distribution with lower percentages of porphyric, however these are compaction indicator. Nevertheless, as the porphyric distributions do not appear continuously in the horizons of all profiles, except the horizons $\mathrm{A}$ and $\mathrm{AB}$ of the profiles $1 \mathrm{~B}$ (soybean/sugarcane not fertirrigated) and 2B (pasture/sugarcana not fertirrigated), in which predominate, in practice indicate poor compaction or incipient. What corroborates the characteristic structure observed in the field in blocks and not laminar, except for 2B profile. 


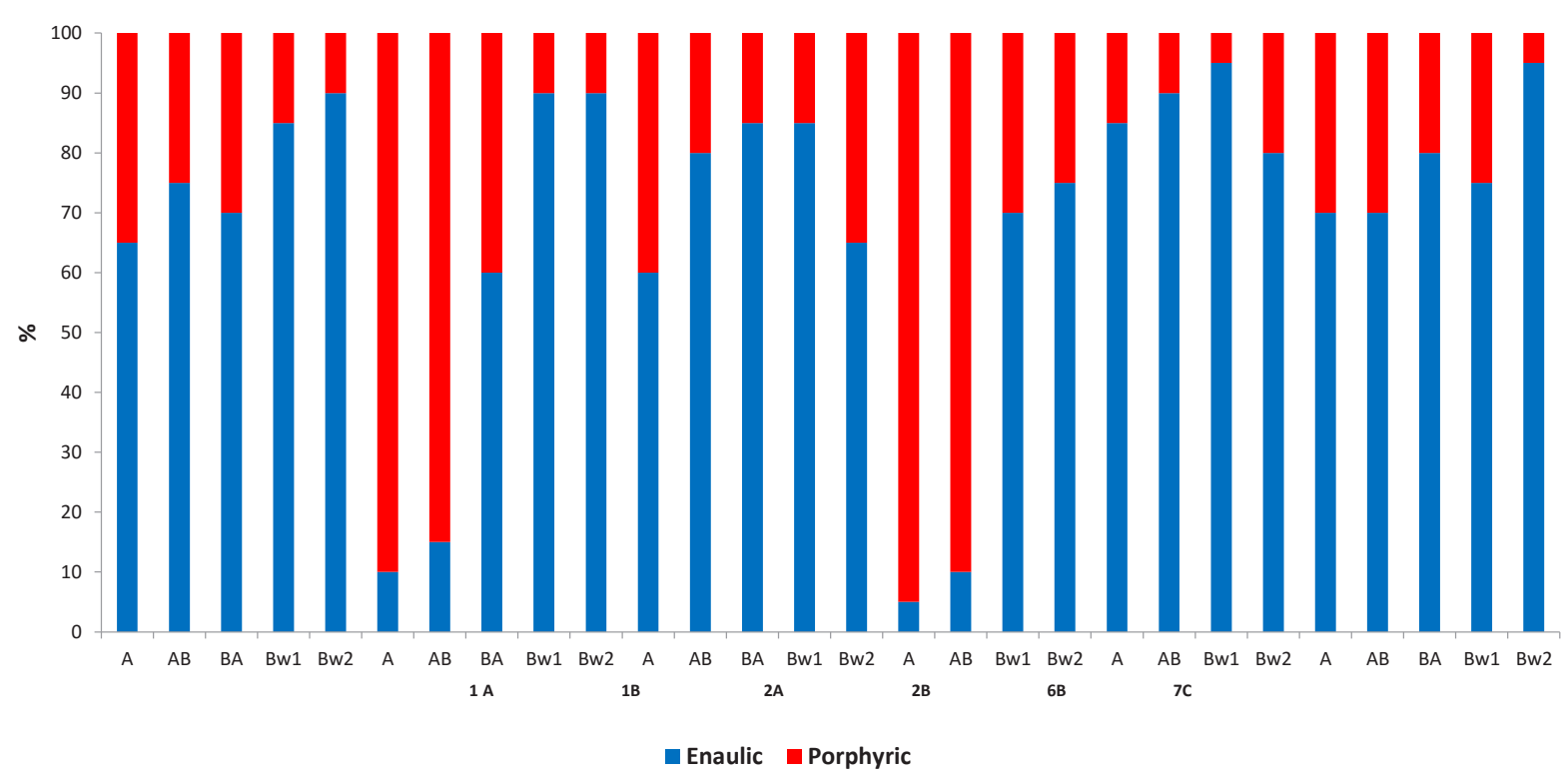

Figure 4 - Relative distribution of horizons of LVdf.

The enaulic distribution appears very small to small, subrounded, with strong pedality to moderate (micro-aggregation indicator), in which the fine material kaolinitic-ferruginous is dissociated of coarse materials quartzose fine, with macroporosity inter-aggregate of medium stacking to fine. The Bw horizons are similar to the previously described, which dominate an enaulic distribution and thin intergranular porosity, as well as channels and/or millimetric cavities. The profiles also have features of filled with its own material of the horizon (table 2).

The profiles 1B (soybean/sugarcane not fertirrigated) and 2B (pasture/sugarcane not fertirrigated) present the horizons $\mathrm{A}$ and $\mathrm{AB}$ as subangular blocks and large subrounded, related to porphyric distribution with weak pedality to moderate, compound of an association between the kaolinitic-ferruginous fine fraction and the medium quartzous gross fraction, and predominance of fine fissured porosity to very thin. In the horizons B and Bw dominates enaulic distribution, strong pedality (micro-aggregated), with small zones porphyric densely in small subrounded blocks. Predominant an intergranular macroporosity of stacking, with canals, cavities and/or millimetric chambers associated with mesofauna, besides, features fill with its own material of the horizon.

The 7C profile (vegetation) also presents kaolinitic-ferruginous fraction, with dominant enaulic distribution and well developed throughout on all the profile. Presents intergranular pores and medium inter-aggregate to thin with the presence of numerous canals, cavities and chambers millimetric to subcentimeters indicative of good biological activity (roots and mesofauna) throughout of all the profile. Thin fasciculate roots occur in the larger pores, in various stages of decomposition. This profile also presents fill features with its own material of the horizon (table 2).

The micromorphological study revealed, that enaulic distribution dominates in the Bw horizons of all profiles, regardless of land use with sugarcane and in all horizons of 7C profile (vegetation). Such relative distribution is typical of Latosols in general and in particular of LVdf, with high iron content. Also was showed that this distribution changes to porphyric, composing small dense zones in the surface horizons mainly in soil with sugarcane, highlighting the profiles 1A (soybean/ sugarcane fertirrigated) and 2A (pasture/sugarcane fertirrigated), associated with small blocks to medium, which is compatible with the compaction process, as observed by Silva et al. (1998) and by Soares et al. (2005b). In these profiles the compaction was interpreted as moderate due to the discontinuation of these compacted zones.

In the profiles $2 \mathrm{~B}$ (pasture/suagrcane not fertirrigated) and $1 \mathrm{~B}$ (soja/suagarcane not fertirrigated) the porphyric structure predominate, being more continuous in the surface horizons $\mathrm{A}$ and $\mathrm{AB}$, 
indicating surface compaction strong. The profile $7 \mathrm{C}$ shows no signs of compaction, as expected. These types of structures are denominated by Bullock et al. (1985) as complex structures (enaulic) and structures in subangular blocks (porphyric). The Figure 5 illustrates the relative distributions, porosity and the filler features, observed in different studied profiles.

In summary, the changes in soil microstructure mainly affect the surface horizons, corroborating field observations, beyond of resitence tests and analytical data of the studied soil profiles, as exposed. In them the effects of direct compression of heavy machinery are responsible for porosity reducing and his change of intergranular for fissured, as well as by changes in those horizons of enaulic relative distribution (micro-aggregate) to porphyric, although in most part of profiles yet discontinuous, except in 2B, corroborating the findings of other authors, such as Kertzman (1996) and Silva et al. (1998).

It was observed that the LVdf already in the beginning of the compacting process after six years of cultivation, and even before of the first reform of the sugarcane field. It is about incipient compaction, discontinuous and superficial clearly associated with soil management by heavy machinery, typical of sugarcane, however with less degradation when combined with vinasse fertirrigation. It was not observed differences attributable to previous uses (soybean and pasture) between profiles.

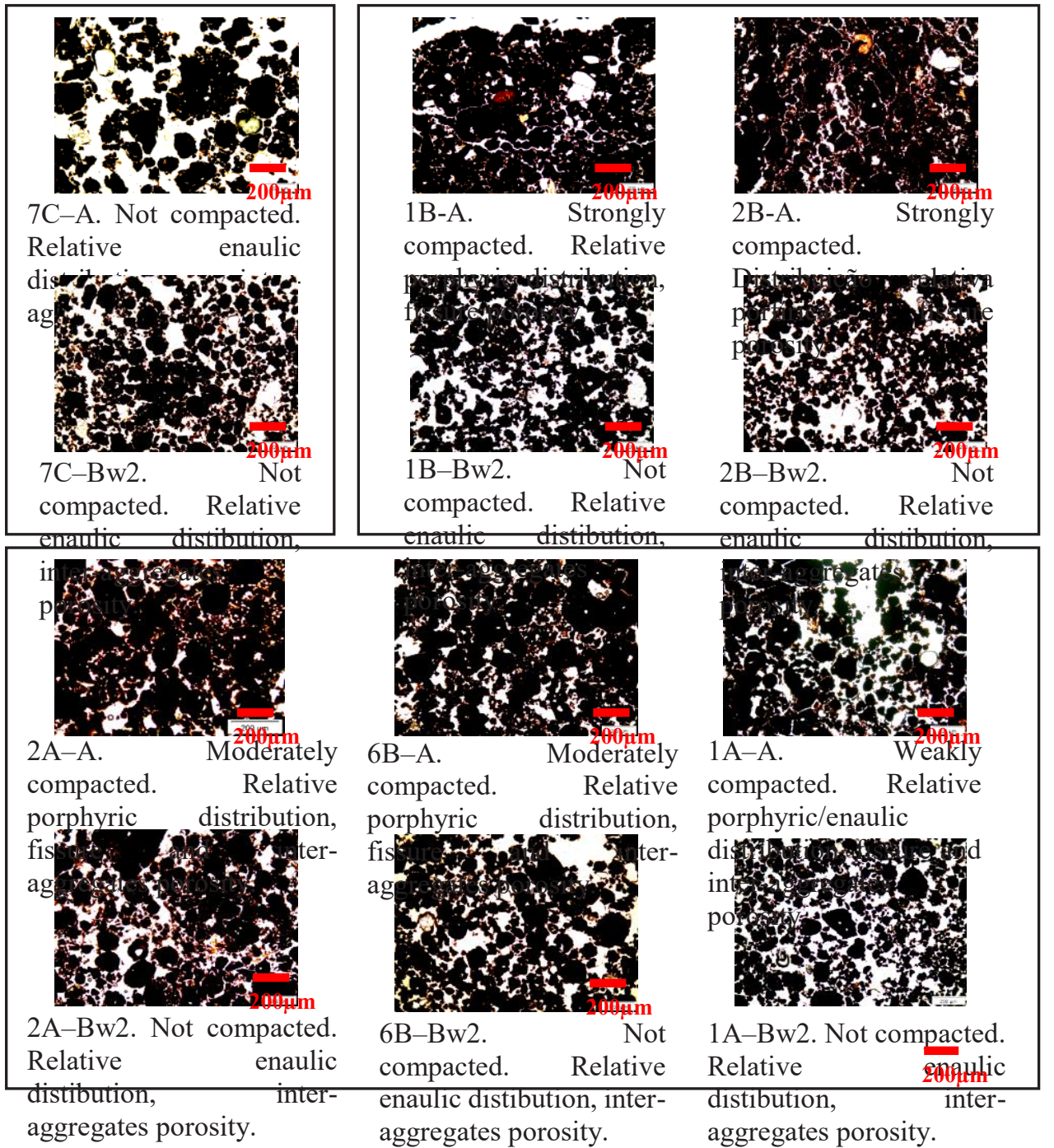

Figure 5 - Photomicrographs of thin sections of representative horizons of LVdf profiles. Notes that the solid phase corresponds to the dark color and the pores in the clear (whitish). 
Was observed that no visible differences were found in plants under field, nor testimonials of the Plant managers to disclose preoccupation with the phenomenon, despite ground monitoring practiced regularly, as usual. Also there was no evidence of erosion process or other process resulting from compaction. Thus the process still not revealed disturbing of the production point of view.

\section{CONCLUSIONS}

1. The macromorphological and analytical indicators that best illustrates the compaction process were: structure, dry consistency, soil density and penetration resistance. Already the micromorphological indicator more efficient was the presence of porphyric microstructure, associated to incipient soil compaction with subangular blocks in field, contrary to the enaulic fabric (micro-aggregates) that indicate no compaction, typical of Bw horizons, associated with granular structure in field. The indicative values of compaction were: $\mathrm{SD} \sim 1,50 \mathrm{~g} \mathrm{~cm}-3$; PD $>3,08 \mathrm{~g} \mathrm{~cm}-3$; PR $>15 \mathrm{MPa}$; TP < $50 \%$.

2. The profiles fertirrigated with vinasse showed better physical quality, with lower values of $\mathrm{SD}(\sim 1,10 \mathrm{~g} \mathrm{~cm}-3)$ and $\mathrm{PR}(<5 \mathrm{MPa})$, related to horizons surface, besides having better preservation of granular structure (micro-aggregated) and macroporosity.

3. The observed compaction was associated with strongly technified management of the sugarcane, with heavy machinery use in all stages of the cultivation process. Result independent of the previous usage, although profiles with previous use as pasture have presented more evidence of compaction, especially the $2 \mathrm{~B}$ Profile, when compared to profiles previously cultivated with soybean, which was explained by inadequate preparation of soil before planting.

\section{ACKNOWLEDGEMENTS}

To CNPq - Conselho Nacional de Pesquisa Científica by financing of research program. The FAPEG - Fundação de Amparo à Pesquisa em Goiás, by fellowship training.

\section{LITERATURE CITED}

BULLOCK, P.; FEDOROFF, N.; JONGERIUS, A.; STOOPS, G.; TURSINA, T. Handbook for soil the section description. Waine research publications, 1985.

CAMARGO, O. A.; ALLEONI, L. R. F. Compactação do solo e o desenvolvimento de plantas. Piracicaba: 1997.

CANASAT - Mapeamento da cana via imagens de satélite de observação da Terra. INPE - Instituto Nacional de Pesquisas Espaciais. Disponível em: <http://www.dsr.inpe.br/canasat/ > Acesso em 17 jan. 2012. CARVALHO, J. M. de; CREMON, C.; MAPELI, N. C.; NUNES, M. C. M.; SILVA, W. M. da; MAGALHÃES, W. de A.; SANTOS, A. D. Análise micromorfométrica de agregados de um Latossolo Vermelho distroférrico sob diferentes sistemas de cultivo. Revista Agrarian, v. 3, n. 10 p. 275-285, 2010.

CASAGRANDE, A. A. Compactação e manejo do solo na cultura da cana-de-açúcar. In: MORAES, M. H.; MULLER, M; M. L.; FOLONI, J. S. S. (Coord). Qualidade física do solo: métodos de estudo - sistema de preparo e manejo do solo. Jaboticabal: Funep, 2002. p. 150 - 197.

CASTRO, S. S. de; ADBALA, K.; SILVA, A. A.; BORGES, V. M. S. A expansão da cana-de-açúcar no Cerrado e no Estado de Goiás: elementos para uma análise espacial do processo. Boletim Goiano de Geografia, Goiânia, V.30, nº 1. p. 171 - 191, jan/jun, 2010.

CASTRO, S. S.; COOPER, M.; SANTOS, M.C. P. VIDAL TORRADO. Micromorfologia do solo: Bases e Aplicações. Tópicos de Ciências do Solo, 3: p.107-164. 2003.

DIAS JUNIOR, M. de S. Compactação do Solo. Viçosa: Sociedade Brasileira de Ciência do Solo. Tópicos em Ciência do Solo, v.1, p.55-94. 2000. 
DORAN, J.W.; PARKIN, T. B. Defining and assessing soil quality. In: DORAN, J.W.; COLEMAN, D.C.; BEZDICEK, D.F.; STEWART, B.A. (ed.). Defining soil quality for a sustainable environment. SSSAJ, Madison, (Publication Number 35), 1994. p.3-22.

EMBRAPA. Sistema Brasileiro de Classificação de solos. Centro Nacional de Pesquisas de Solos, $2^{\text {a }}$ edição. Rio de Janeiro: EMBRAPA, 2006.

EMBRAPA. Manual de métodos de análise de solos. Centro Nacional de Pesquisas de Solos, $2^{\mathrm{a}}$ ed. Rio de Janeiro: Embrapa, 1997.

KERTZMAN, F. F. Modificações na estrutura e no comportamento de um latossolo roxo provocadas pela compactação. Tese (Doutorado). Universidade de São Paulo, 1996. p.152

LATRUBeSSE, M. E.; CARVAlHO, M. T. Geomorfologia do Estado de Goiás e Distrito Federal. Secretaria da Indústria e Comércio, Superintendência de Geologia e Mineração Goiânia, 2006.

OLIVEIRA, G.C.; DIAS JÚNIOR, M.S.; RESCK, D.V.S.; CURI, N. Alterações estruturais e comportamento compressivo de um Latossolo Vermelho distrófico argiloso sob diferentes sistemas de uso e manejo. Pesquisa Agropecuária Brasileira. Brasília, v.38, n.2, p.291-299, 2003.

OTTO, R.; SILVA, A. P.; FRANCO, E. C. A.; TRIVELIN, P. C. O. High soil penetration resistance reduces sugarcane root system development. Soil \& Tillage Research, n. 117, p. 201-210, 2011.

PACHECO, E. P.; CANTALICE, J. R. B. Compressibilidade, resistência a penetração e intervalo hídrico ótimo de um Argissolo Amarelo cultivado com cana-de-açúcar nos tabuleiros costeiros de Alagoas. Revista Brasileira de Ciências do Solo, Viçosa, v. 35, p. 403-415, 2011.

PEDROTTI, A.; MÉLLO JÚNIOR, A. V. Avanços em ciência do solo: a física do solo na produção agricola e qualidade ambiental. São Cristovão, 2009.

REICHERT, J.M. et al. Compactação do solo em sistemas agropecuários e florestais: identificação, efeitos, limites críticos e mitigação. Tópicos Ciência Solo, v.5 p.49-134, 2007.

REICHERT, J. M.; REINERT, J. D.; SUZIKI, L. E. A. S.; HORN, R. Mecânica do solo. In: LIER, Q. J. V. (editor) Física do solo. Viçosa: Sociedade Brasileira de Ciência do Solo, 2010. p. 29 - 102.

REYNOLDS, W. D.; BOWMAN, B. T.; DRURY, C. F.; TAN, C. S. \& LU, X. Indicators of good soil physical quality: density and storage parameters. Geoderma, 110:131-146, 2002.

RIBEIRO, A. C.; NOVAIS, R. F. de. BAHIA FILHO, A. F. de C. Efeitos da vinhaça sobre a dispersão de argila de amostras de Latossolos. Revista Ceres. Ceres, v.30, n.167, p.12-18, 1983.

SANTOS, R. D. dos; LEMOS, R. C. de; SANTOS, H. G. dos; KER, J. C.; ANJOS, L. H. C. dos. Manual de descrição e coleta de solo no campo. EMBRAPA. $5^{\text {a }}$ Ed. Viçosa, 2005.

SCHNEIDER, P.; KLAMT, E. GIASSON, E. Morfologia do solo: subsídio para caracterização e interpretação de solos a campo. Guaíba: Agrolivros, 2007.

SEPLAN, Secretaria de Planejamento do Estado de Goiás. Regiões de planejamento do Estado de Goiás. Goiânia: SEPLAN, 2006.

SEVERIANO, E. da C.; OLIVEIRA, G. C. de; DIAS JÚNIOR, M. de S.; CASTRO, M. B. de; OLIVEIRA, L. F. V. de. Compactação de solos cultivados com cana-de-açúcar: I modelagem e quantificação da compactação adicional após as operações de colheita. Engenharia Agrícola, Jaboticabal, v.30, n.3, p.404-413, maio/jun. 2010.

SEVERIANO, E. da C.; OLIVEIRA, G. C. de; DIAS JÚNIOR, M. de S. OLIVEIRA, L. F. C. de; CASTRO, M. B. de Pressão de preconsolidação e intervalo hídrico ótimo com indicadores de alterações estruturais de um Latossolo e de um Cambissolo sob cana-de-açúcar. Revista Brasileira de Ciências do solo, v.32, p.1419-1427, 2008.

SILVA, A. A.; CASTRO, S. S. Dinâmica de uso da terra e expansão da cana-de-açúcar entre os anos de 2004 a 2010, na microrregião de Quirinópolis, Goiás. In: PIETRAFESA, J. P.; SILVA, S. D. de (org.). Transformações no Cerrado: progresso, consumo e natureza. Goiânia: Ed. Da PUC Goiás, 2011. p. 155-170. SILVA, A. J. N. RIBEIRO, M. R. MERMUT, A. R. BENKE, M. B. Influência do cultivo contínuo da cana-de-açúcar em latossolos amarelos coesas do Estado de Alagoas: propriedades micromorfológicas. Revista Brasileira de Ciência do Solo, 22:515-525, 1998. 
SILVA, R. B.; LANÇAS, K. P.; MIRANDA, E. E. V.; SILVA, F. A. M.; BAIO, F. H. R. Estimation and evaluation of dynamic properties as indicators of changes on soil structure in sugarcane fields of São Paulo state - Brasil. Soil \& Tillage Reserch. V. 103 p. 265-270, 2009.

SILVA, A. J. N. DA; CABEDA, M. S. V. Compactação e compressibilidade do solo sob sistemas de manejo e níveis de umidade. Revista Brasileira de Ciência do solo. n. 30 p. 921-930, 2006.

SILVA, M. A. S. da; GRIEBELER, N. P.; BORGES, L. C. Uso de vinhaça e impactos nas propriedades do solo e lençol freático. R. Bras. Eng. Agríc. Ambiental, v.11, n.1, p.108-114, 2007.

SOARES, J. L. N.; ESPÍNDOLA, C. R.O; CASTRO, S. S. de. Alteração física e morfológica em solos cultivados sob sistema tradicional de manejo. Revista Brasileira de Ciências do Solo, v. 29. p. 1005-1014, 2005 (a).

SOARES, J. L. N.; ESPINDOLA, C. R.; FOLONI, L. L. Alteração física e morfológica em solos cultivados com citros e cana-de-açúcar, sob sistema tradicional de manejo. Ciência Rural, Santa Maria, v. 35, n.2, p. 353-359, 2005 (b).

SOUZA JUNIOR, J. J. Mapa de Geologia. In: Projeto RADAMBRASIL. Levantamento de Recursos Naturais, 31. Folha SE.22. Rio de Janeiro: 1983.

STOLF, R. Teoria e teste experimental de fórmulas de transformação dos dados de penetrômetro de impacto em resistência do solo. Revista Brasileira de Ciência do Solo, Campinas, v.15, n.2, p.229-35, 1991.

STOLF, R.; FERNANDES, J. \& FURLANI NETO, V. Recomendação para uso do penetrômetro de impacto modelo IAA/Planalsucar-Stolf. R. STAB - Açúcar, Álcool e Subprodutos, 1:18-23, 1983.

STOOPS, G. Guidelines for analysis and description of soil and regolith thin section. Soil Science Society of America. Madison, Wisconsin, 2003.

TRINDADE, T. P. da; CARVALHO, C. A. B. de; LIMA, D. C. de; BARBOSA, P. S. de A.; SILVA, C. H. de C.; MACHADO, C. C. Compactação dos solos: fundamentos teóricos e práticos. Viçosa: Ed. UFV, 2008. 95 p. VAZ, C. M. P.; PRIMAVESI, O.; PATRIZZI, V. C.; IOSSI, M. de F. Influência da umidade na resistência do solo medida com penetrômetro de impacto. Comunicado técnico 51. MAPA. São Paulo, 2002.

Submitted september 2015

Accepted october 2015 